\title{
Analisis Risiko Investasi dan Return Saham pada Industri Telekomunikasi yang Terdaftar di Bursa Efek Indonesia
}

\author{
Arna Suryani \\ Dosen Fakultas Ekonomi Universitas Batanghari Jambi
}

\begin{abstract}
This study aims to know and analyze how the effect of invesment risk on stock returns in the telecommunications industry listed in Indonesia Stock Exchange for the period 2013-2017. Invesment risk is measured by interest rate risk, market risk, inflation risk, business risk, financial risk and liquidity risk. The research method was analyzed with descriptive and using a linear regression analysis with panel data. Statistical test by testing the hypothesis $F$ simultaneosly and t test partially, as well as to determine how much the coefficient of determanation $\left(R^{2}\right)$. Besed on the results of the study indicate that simultaneous investment risk has a positive and significant effect on stock returns with a large influence of $72.5 \%$. Partially invesment risk is only market risk and business risk which has asignificant effect on stock prices, while invesment risk represented by interest rates, inflation risk, financial risk and liquidation risk does not have a sisnificant effect on stock pices. This proves that the market responds and is more interested in paying attention to market risk and business risk in valuing companies reflected in stock price
\end{abstract}

Keywords: Investment Risk, interest risk, market risk, inflation risk, bisnis risk, financial risk, liquidity risk, stock return

\section{PENDAHULUAN}

Investasi merupakan penempatan sejumlah dana pada saat ini dengan harapan untuk memperoleh keuntungan di masa mendatang. Investasi berkaitan dengan pengujian bagaimana pasar modal menetapkan harga sekuritas dengan mempelajari bagaimana investor individu memilih di antara berbagai macam aset keuangan berdasarkan tingkat kesukaannya pada risiko dan return. Return merupakan salah satu faktor yang memotivasi investor untuk berani menanggung resiko. Return dan risiko merupakan dua faktor yang tidak terpisahkan dalam mempertimbangkan layak atau tidaknya sebuah investasi. Investor pada umumnya tidak menyukai risiko sehingga investor akan mempertimbangkan risiko-risiko yang akan dihadapi sebelum melakukan investasi. Jadi Salah satu bagian terpenting dalam mempelajari investasi adalah bagaimana kita mengukur risiko dan return. Setiap investor yang melakukan investasi saham memiliki tujuan yang sama, yaitu mendapatkan keuntungan saham yang meliputi capital gain, yaitu selisih positif antara harga jual dan harga beli saham serta dividen tunai yang diterima dari emiten. Saham memungkinkan pemodal mendapatkan return atau keuntungan (capital gain) dalam jumlah yang besar untuk jangka waktu yang cukup singkat. Namun seberapa besar hasil yang akan diperoleh dan seberapa besar penyimpangan dari hasil yang diharapkan tidak dapat diketahui secara pasti oleh investor. (Adisetiawan, 2018)

Pertimbangan yang dilakukan investor adalah menanggung risiko tertentu guna memperoleh return tertentu, atau semakin besar resiko yang berani ditanggung investor maka semakin besar pula return yang diharapkan. Untuk mengantisipasi dari fluktuasi return dan risk yang ada, investor biasanya melakukan investasi di beberapa saham atau portofolio saham dengan harapan fluktuasi dari return saham-saham yang terbentuk di portofolio tidak terlalu tajam. Terjadinya pergerakan harga saham secara fluktuatif dari masingmasing perusahaan menunjukkan bahwa harga saham yang terus bergerak seiring dengan permintaan pembelian saham dari investor. Tentunya hal ini akan menyebabkan risiko tersendiri. Para investor mengambil return (hasil) yang maksimal pada risiko tertentu untuk memperoleh hasil tertentu pada risiko yang minimal. Artinya adalah risiko investasi yang timbul merupakan bentuk dari realita yang terjadi yang mana risiko itu selalu saja sulit untuk dihindari namun diusahakan terjadi dalam jumlah yang sangat minim. Perdagangan sekuritas pada sektor industri telekomunikasi saat ini menjadi salah satu bisnis yang menguntungkan, hal ini ditunjukkan dengan Pergerakan harga saham yang tercatat di Bursa Efek Indonesia (BEI) sehingga menyebabkan banyak investor yang tertarik untuk terlibat dalam bisnis di bidang telekomunikasi hal ini menunjukkan seberapa besar minat investor untuk membeli saham-saham dari masing-masing perusahaan telekomunikasi di Indonesia. (Adisetiawan dan Yunan, 2016) 
Penelitian ini bertujuan untuk menguji dan menganaisis pengaruh risiko investasi dengan indikator risiko suku bunga, risiko pasar, risiko inflasi, risiko bisnis, risiko finansial dan risiko likuiditas secara parsial terhadap return saham pada Industri Telekomunikasi yang terdaftar di bursa efek Indonesia Periode 20132017.

\section{Landasan Teori \\ Risiko Investasi}

Investor dalam mengambil setiap keputusan investasi adalah selalu berusaha untuk meminimalisir berbagai risiko yang timbul, baik risiko yang bersifat jangka pendek maupun risiko yang bersifat jangka panjang. Setiap perubahan berbagai kondisi mikro dan makro ekonomi akan turut mendorong terbentuknya berbagai kondisi yang mengharuskan seorang investor memutuskan apa yang harus dilakukan dan strategi apa yang diterapkan agar ia tetap memperoleh return yang diharapkan. Menurut Fahmi (2012), Dengan begitu risiko investasi dapat kita artikan sebagai kemungkinan terjadinya perbedaan antara actual return and expected return $[E(R)]$. Setiap keputusan investasi memiliki keterkaitan yang kuat dengan risiko, sehingga risiko selalu dijadikan barometer utama untuk dianalisis jika investasi dilakukan. Analis risiko adalah proses pengukuran dan penganalisaan risiko disatukan dengan keputusan keuangan dan investasi. (Adisetiawan, 2017)

\section{Risiko Suku Bunga}

BI rate merupakan suku bunga acuan yang menurut Tandelilin (2007) perubahan suku bunga bisa mempengaruhi variabilitas return suatu investasi. Perubahan suku bunga akan mempengaruhi harga saham secara terbalik, cateris paribus. Artinya jika suku bunga meningkat maka harga saham akan turun demikian pula sebaliknya. Untuk dapat mengukur tingkat suku bunga dapat diambil data dari BI Rate.

\section{Risiko Pasar}

Halim (2005) Risiko Pasar adalah risiko yang timbul akibat kondisi perekonomian negara yang berubah-ubah dipengaruhi oleh resesi dan kondisi perekonomian lain. Risiko pasar merupakan risiko yang tidak dapat dihilangkan dengan melakukan diversifikasi, karena fluktuasi risiko ini di pengaruhi faktorfaktor makro yang dapat mempengaruhi pasar secara keseluruhan. Risiko pasar dapat dihitung dengan melihat Indeks Harga Saham Gabungan (IHSG) tahunan.

\section{Risiko Inflasi}

Menurut Tandelilin (2007) Risiko Investasi, bahwa Inflasi yang meningkat akan mengurangi kekuatan daya beli rupiah yang telah diinvestasikan. Oleh karenanya, risiko inflasi juga bisa disebut sebagai risiko daya beli. Jika inflasi mengalami peningkatan, investor biasanya menuntut tambahan premium inflasi untuk mengkompensasi penurunan daya beli yang dialaminya. Untuk dapat mengukur risiko inflasi dapat dilihat dari tingkat inflasi yang ada pada Data Bank Indonesia yang berisi laporan Inflasi (Indeks Harga Konsumen) berdasarkan perhitungan inflasi tahunan.

\section{Risiko Bisnis}

Risiko bisnis adalah ketidak pastian yang melekat dalam proyeksi pengembalian atas modal yang diinvestasikan, ketidak pastian pada perkiraan pendapatan operasi perusahaan di masa mendatang. Menurut Gitman dan Jiehnk (2008) business risk adalah suatu risiko yang merupakan tingkat ketidak pastian yang berhubungan dengan pendapatan dari suatu investasi dan kemamouan dari suatu investasi dalam membayar sejumlah return kepada investor. Menurut Brigham dan Houston (2006) Risiko didefinisikan sebagai peluang atau kemungkinan terjadinya beberapa peristiwa yang tidak menguntungkan. Risiko bisnis adalah ketidakpastian yang dihadapi perusahaan dalam menjalankan kegiatan bisnisnya. Risiko bisnis tersebut merupakan risiko yang mencakup intrinsic business risk, financial leverage risk, dan operating leverage risk. Earning Volatility atau biasa disebut Business Risk adalah variabel indikator yang menggambarkan risiko yang diciptakan akibat tidak efisiennya operasional perusahaan, dimana terdapat kegagalan internal kontrol yang mengakibatkan kerugian yang tidak diperkirakan sebelumnya diukur dengan standar deviasi dari EBIT dibagi dengan total aktiva, dengan rumus sebagai berikut: 
Earning Volatility $=\frac{\text { StandarDeviasi dariEBIT }}{\text { Total Asset }}$

\section{Risiko Finansial}

Risiko finansial merupakan contoh dari risiko sistematis yang ditimbul oleh perusahaan. Menurut Fahmi (2012) Risiko Finansial adalah memakai utang dalam membiayai perusahaan, maka akan menyebabkan utang terjadi peningkatan hingga berefek pada risiko yang ikut meningkat juga sehingga otomatis risiko finansial akan ikut meningkat. Di mana risiko keuangan diukur dengan rasio variabilitas laba pemegang saham yaitu rasio laba sebelum bunga dan pajak dengan laba bersih sebelum pajak, dengan rumus sebagai berikut:

Risiko Financial $=\frac{\text { Earning BeforeInterest and Taxes }}{\text { Earning Before } \text { Taxes }}$

\section{Risiko Likuiditas}

Menurut Tandelilin (2007), Risiko Likuiditas ini adalah risiko yang berkaitan dengan kecepatan suatu sekuritas yang diterbitkan perusahaan bisa diperdagangkan di pasar sekunder. Semakin cepat suatu sekuritas diperdagangkan, semakin likuid sekuritas tersebut, demikian sebaliknya. Semakin tidak likuid suatu sekuritas semakin besar pula risiko likuiditas yang dihadapi perusahaan. Current ratio yang tinggi maka semakin baiklah posisi para kreditor, oleh karena terdapat kemungkinan yang lebih besar bahwa utang perusahaan itu akan dapat dibayar pada waktunya. Adapun formulasi dari Current Ratio $(C R)$ adalah sebagai berikut :

\section{Current ratio $=\frac{\text { Aktiva Lancar }}{\text { Hutang Lancar }} \times 100 \%$}

\section{Return Saham}

Return merupakan selisih antara harga jual dengan harga beli ditambah kas lain (dividen). Menurut Husnan (2005). Return adalah ukuran yang mengukur besarnya perubahan kekayaan investor baik kenaikan maupun penurunan serta menjadi bahan pertimbangan untuk membeli atau mempertahankan sekuritas. Ekspresi untuk menghitung return saham yang diterima selama periode tertentu $t$ atas aset $i$ berdasarkan data historis (persentase harga saham), sebagai berikut:

$\mathrm{R}_{\mathrm{t}}=\frac{\text { Pit }- \text { Pit }-1}{\text { Pit }-1}$

dimana: $\mathrm{Rt}=$ Return saham pada periode $\mathrm{t} ; \mathrm{P}_{\mathrm{it}}=$ Harga atau nilai pada akhir periode $\mathrm{t} ; \mathrm{P}_{\mathrm{it}-1}=$ Harga atau nilai pada periode sebelumnya $(\mathrm{t}-1)$

\section{Pengembangan Hipotesis}

Harga sebuah saham dipengaruhi oleh tingkat suku bunga. Pengaruh tersebut bersifat negatif, jika tingkat suku bunga naik maka harga saham akan mengalami penurunan. Apabila suku bunga mengalami penurunan, maka investasi di bursa saham menjadi lebih menarik karena investor cenderung untuk mencari tingkat pengembalian yang lebih tinggi. Semakin tinggi risiko pasar akan semakin tinggi tingkat return yang disyaratkan. Tingginya risiko mempunyai hubungan positif terhadap return saham. Peningkatan IHSG menunjukkan kondisi pasar modal sedang meningkat (bullish), sebaliknya jika menurun menunjukkan kondisi pasar modal sedang menurun (bearish). Untuk itu, seorang investor harus memahami pola perilaku harga saham di pasar modal. Meningkatnya inflasi secara relatif adalah signal negatif bagi investor. Inflasi yang tinggi akan menyebabkan daya beli masyarakat menurun. Semakin tinggi inflasi akan semakin menurunkan tingkat profitabilitas perusahaan. Dan sebaliknya jika semakin rendah inflasi maka akan semakin meningkatkan tingkat profitabilitas perusahaan. Risiko bisnis merupakan ketidakpastian yang melekat dalam proyeksi pengembalian atas modal yang diinvestasikan, ketidakpastian pada perkiraan pendaapatan operasi perusaahaan dimasa mendatang. Risiko bisnis ini berhubungan dengan kemampuan perusahaan menjalankan modal akan berpengaruh positif terhadap peningkatan return saham. Semakin tinggi financial risk/risiko keuangan, maka semakin besar risiko tambahan pada perusahaan akibat keputusan penggunaan hutang dalam struktur modal perusahaan dan begitu pula sebaliknya. dari sisi likuiditas, apabila saham mempunyai tingkat yang likuiditas nya rendah (illiquid) maka biaya likuidasinya akan besar. Dengan kenyataan tersebut, para investor pasti mengharapakan pengembalian yang lebih tinggi 
supaya biaya likuidasi tersebut dapat terkompensasi. Jika current ratio semakin menurun berarti menunjukkan suatu likuiditas perusahaan menurun yang akan berpengaruh terhadap return saham yang akan diperoleh oleh investasi.

\section{Hipotesis}

Hipotesis penelitian dapat dirumuskan sebagai berikut:

H1: risiko suku bunga, risiko pasar, risiko inflasi, risiko bisnis, risiko finansial, dan risiko likuiditas berpengaruh secara simultan dan signifikan terhadap return saham

$\mathrm{H} 2$ : risiko suku bunga berpengaruh secara parsial dan signifikanterharap return saham.

$\mathrm{H} 3$ : risiko pasar berpengaruh secara parsial dan signifikan terharap return saham.

H4: risiko inflasi berpengaruh secara parsial dan signifikan terharap return saham.

H5: risiko bisnis berpengaruh secara parsial dan signifikan terharap return saham.

H6: risiko finansial berpengaruh secara parsial dan signifikan terharap return saham.

H7: risiko likuiditas berpengaruh secara parsial dan signifikan terharap return saham.

\section{METODE PENELITIAN}

Objek penelitian ini adalah perusahaan telekonumikasi yang terdaftar di bursa efek Indonesia periode tahun 2013 sampai 2017. Teknik penarikan sampel menggunakan sampel jenuh yaitu populasi sama dengan jumlah sampel. Sumber data yang digunakan dalam penelitian ini adalah data sekunder dilakukan dengan metode kepustakaan (Library Research). Data penelitian ini bersumber dari: (1) direktori pasar modal Indonesia (Indonesia Capital Market Directory) berupa data tentang iktisar laporan keuangan dan pasar modal, (2). website bursa efek Indonesia (www.idx.co.id) berupa data laporan keuangan tahunan serta catatan atas laporan keuangan, (3). website www.yahoofinance.com. berupa data harga saham emiten dan indeks harga saham gabungan diambil dari Harga saham harian $\left(\mathrm{P}_{\mathrm{it}}\right)$ adalah harga saham i pada tanggal $\mathrm{t}$ setelah penutupan (closing price). Indek harga saham gabungan (IHSG) selama periode estimasi dan pengamatan, digunakan untuk menghitung return pasar $\left(\mathrm{Rm}_{\mathrm{t}}\right)$.

Metode analisis data yang digunakan dalam penelitian ini adalah metode analisis kuantitatif. Menurut Sunyoto (2013) analisis kuantitatif adalah analisis yang menggunakan rumus-rumus statistik yang disesuaikan dengan judul penelitian dan rumusan masalah, untuk perhitungan angka-angka dalam rangka menganalisis data yang diperoleh. Dalam penelitian ini data yang diperoleh akan di analisis dengan menggunakan alat analisis regresi linear berganda dengan data panel dengan rumus persamaan regresi yaitu: $\mathrm{Y}_{\mathrm{it}}=\mathrm{a} 0+\mathrm{b} 1 \mathrm{X}_{1 \mathrm{it}}+\mathrm{b} 2 \mathrm{X}_{2 \mathrm{it}}+\mathrm{b} 3 \mathrm{X}_{3 \mathrm{it}}+\mathrm{b} 4 \mathrm{X}_{4 \mathrm{it}}+\mathrm{b} 5 \mathrm{X}_{5 \mathrm{it}}+\mathrm{b} 6 \mathrm{X}_{6 \mathrm{it}}+\mu_{\mathrm{it}}$

Keterangan : $\mathrm{i}=$ Unit Cross Section, $\mathrm{t}=$ Periode Waktu, $\mathrm{b}=$ koefisien slope dengan dimensi $\mathrm{K} \times 1$, dimana $\mathrm{K}$ adalah banyaknya peubah bebas, $\mu=$ Error, $\mathrm{Y}_{\mathrm{it}}=$ Peubah tak bebas unit individu ke-i dan unit waktu ke-t, $\mathrm{X}_{\mathrm{it}}=$ Peubah bebas untuk unit individu ke-i dan unit waktu ke-t, $\mathrm{X}_{1}=$ Risiko Suku Bunga, $\mathrm{X}_{2}=$ Risiko pasar, $\mathrm{X}_{3}=$ Risiko Inflasi, $\mathrm{X}_{4}=$ Risiko Bisnis, $\mathrm{X}_{5} \quad=$ Risiko finansial $\mathrm{X}_{6}=$ Risiko Likuiditas. Uji statistik dilakukan dengan uji asumsi klasik yang digunakan adalah Uji Normalitas, Uji Multikolinearitas, Uji Heteroskedastisitas, Uji Autokorelasi kemudian dilakukan uji hiposesis uji F dan uji t.

\section{HASIL DAN PEMBAHASAN}

Uji asumsi klasik uji normalitas diperoleh data berdistribusi normal, tidak terjadi gejala multikolinearitas antara variabel bebas, tidak terjadi gejala heteroskedastisitas pada model regresi data panel, sehingga model regresi layak dipakai untuk variabel Risiko Suku Bunga, Risiko Pasar, Risiko Inflasi, Risiko Bisnis, Risiko Finansial, Risiko Likuiditas dan Return saham, model regresi terbebas dari masalah autokorelasi atau tidak ada autokorelasi positif atau negatif. Berdasarkan hasil analisis regresi berganda diperoleh koefisien untuk variabel bebas dapat dilihat pada tabel berikut. 
Tabel 2

Regresi

\begin{tabular}{|ll|r|r|r|}
\hline & \multicolumn{2}{|c|}{ Unstandardized Coefficients } & \multicolumn{2}{|c|}{ Standardized Coefficients } \\
\cline { 3 - 5 } Model & B & Std. Error & \multicolumn{1}{c|}{ Beta } \\
\hline 1 & (Constant) &,- 028 &, 104 &,- 044 \\
& Risiko Suku Bunga_X1 &,- 044 &, 106 &, 601 \\
Risiko Pasar_X2 &, 604 &, 120 &,- 159 \\
& Risiko Inflasi_X3 &,- 159 &, 113 &,- 384 \\
& Risiko Bisnis_X4 &,- 376 &, 118 &,- 043 \\
& Risiko Finansial_X5 &,- 043 &, 182 &, 042 \\
\hline
\end{tabular}

Sumber: data olahan

Persamaan regresi data panel diatas maka dapat dianalisa sebagai berikut :

- Konstanta (a) sebesar -0,028.

- Koefisien Regresi variabel, Risiko suku bunga $\left(X_{1}\right)$ sebesar -0,044. Nilai koefisien yang negatif menunjukkan bahwa Risiko suku bunga $\left(\mathrm{X}_{1}\right)$ berpengaruh negatif terhadap return saham. Hal ini menunjukkan bahwa dengan penambahan risiko bunga $1 \%$ maka akan menurunkan return saham sebesar 0,044\%.

- Koefisien regresi Variabel risiko pasar $\left(\mathrm{X}_{2}\right)$ sebesar 0,604. Nilai koefisien yang positif menunjukkan bahwa risiko pasar $\left(\mathrm{X}_{2}\right)$ berpengaruh positif terhadap return saham Hal ini menunjukkan bahwa dengan penambahan risiko pasar $1 \%$ maka akan meningkatkan return saham sebesar 0,604\%.

- Koefisien regresi variabel risiko inflasi $\left(X_{3}\right)$ sebesar -0,159. Nilai koefisien yang negatif menunjukkan bahwa risiko inflasi $\left(\mathrm{X}_{3}\right)$ berpengaruh negatif terhadap return saham. Hal ini menunjukkan bahwa dengan penambahan $1 \%$ risiko inflasi maka sebesar $1 \%$ akan menurunkan return saham sebesar $0,159 \%$.

- Koefisien regresi variabel risiko Bisnis $\left(\mathrm{X}_{4}\right)$ sebesar -0,376. Nilai koefisien yang negatif menujukkan bahwa risiko bisnis $\left(\mathrm{X}_{4}\right)$ berpengaruh negatif terhadap return saham. Hal ini menunjukkan bahwa dengan penambahan $1 \%$ risiko bisnis maka sebesar $1 \%$ akan menurunkan return saham sebesar 0,376\%.

- Koefisien regresi variabel risiko finansial $\left(\mathrm{X}_{5}\right)$ sebesar $-0,043$. Nilai koefisien yang negatif menunjukkan bahwa risiko finansial $\left(\mathrm{X}_{5}\right)$ berpengaruh negatif terhadap return saham. Hal ini menunjukkan bahwa dengan penambahan $1 \%$ risiko finansial maka sebesar $1 \%$ akan menurunkan return saham sebesar $0,043 \%$.

- Koefisien regresi variabel risiko likuiditas $\left(\mathrm{X}_{6}\right)$ sebesar 0,063. Nilai koefisien yang positif menunjukkan bahwa risiko likuiditas $\left(\mathrm{X}_{6}\right)$ berpengaruh positif terhadap return saham. Hal ini menunjukkan bahwa dengan penambahan risiko likuiditas sebesar 1\% maka akan meningkatkan return saham sebesar 0,063.

Tabel 3 dibawah ini dapat dilihat bahwa nilai $F$ hitung sebesar 13,720 sedangkan nilai $F$ tabel sebesar 2,53 dengan $\alpha=0,05$. Oleh karena itu nilai $F$ hitung lebih besar dari $F$ tabel ( 13,720 > 2,53 ) maka $\mathrm{H}_{\mathrm{o}}$ ditolak dan menerima $\mathrm{H}_{\mathrm{a}}$, dan nilai sig lebih kecil dari $0,05(0,000<0,05)$ maka $\mathrm{H}_{\mathrm{o}}$ diterima dan menolak $\mathrm{H}_{\mathrm{a}}$, maka dapat disimpulkan bahwa ada pengaruh signifikan antara risiko suku bunga, risiko pasar, risiko inflasi, risiko bisnis, risiko finansial, dan risiko likuiditas secara simultan terhadap return saham pada Industri Telekomunikasi di Bursa Efek Indonesia periode 2013-2017 pada tingkat kepercayaan 95\%.

Tabel 3

Uji F (Simultan)

\begin{tabular}{|l|r|r|r|r|r|}
\hline \multicolumn{1}{|c|}{ Model } & \multicolumn{1}{c|}{ Sum of Squares } & \multicolumn{1}{c|}{ Df } & Mean Square & \multicolumn{1}{c|}{ F } & Sig. \\
\hline Regression & 22,667 & 6 & 3,778 & 13,720 &, $000^{\mathrm{b}}$ \\
\hline Residual & 6,333 & 23 &, 275 & & \\
\hline Total & 29,000 & 29 & & & \\
\hline
\end{tabular}

Sumber: data olahan 
Uji secara parsial dengan menggunakan uji t untuk menjawab hipotesis 2 sampai 7 yang ditunjukkan pada tabel 4 berikut.

Tabel 4

Hasil t

\begin{tabular}{|c|c|c|c|c|c|}
\hline \multirow{2}{*}{ Model } & \multicolumn{2}{|c|}{ Unstandardized Coefficients } & \multirow{2}{*}{\begin{tabular}{|c} 
Standardized Coefficients \\
Beta
\end{tabular}} & \multirow{2}{*}{$\mathrm{t}$} & \multirow{2}{*}{ Sig. } \\
\hline & B & Std. Error & & & \\
\hline (Constant) &,- 028 & ,104 & &,- 266 & ,793 \\
\hline Risiko Suku Bunga_X1 &,- 044 &, 106 &,- 044 &,- 414 & 683 \\
\hline Risiko Pasar_X2 & ,604 &, 120 & ,601 & 5,049 &, 000 \\
\hline Risiko Inflasi_X3 &,- 159 &, 113 &,- 159 & $-1,404$ & ,174 \\
\hline Risiko Bisnis_X4 &,- 376 & 118 &,- 384 & $-3,181$ & ,004 \\
\hline Risiko Finansial_X5 &,- 043 &, 182 &,- 043 &,- 235 &, 816 \\
\hline Risiko Likuiditas_X6 & ,063 & ,265 & ,042 & ,239 &, 813 \\
\hline
\end{tabular}

Sumber: data olahan

Tabel 4 di atas dapat dilihat Variabel risiko suku bunga (X1) mempunyai t hitung $-0,414<\mathrm{t}$ tabel 2,0686 dengan nilai sig sebesar 0,683. maka $\mathrm{H}_{\mathrm{a}}$ ditolak $\mathrm{H}_{\mathrm{o}}$ diterima yang menunjukkan bahwa variabel risiko suku bunga tidak berpengaruh signifikan terhadap return saham. Variabel risiko pasar (X2) mempunyai $t$ hitung 5,049 > t tabel 2,0686 dengan nilai sig sebesar 0,000 maka $\mathrm{H}_{\mathrm{o}}$ ditolak $\mathrm{H}_{\mathrm{a}}$ diterima yang menunjukkan bahwa variabel risiko pasar berpengaruh signifikan terhadap return saham. Variabel risiko suku inflasi (X3) mempunyai t hitung $-1,404<\mathrm{t}$ tabel 2,0686 dengan nilai sig sebesar 0,174. Nilai signifikan lebih besar dari tingkat sig yang diharapkan $(0,174>0,05) \mathrm{H}_{\mathrm{a}}$ ditolak $\mathrm{H}_{\mathrm{o}}$ diterima yang menunjukkan bahwa variabel risiko suku bunga tidak berpengaruh signifikan terhadap return sahama. Variabel risiko suku bisnis (X4) mempunyai thitung $-3,181<\mathrm{t}$ tabel 2,0686 dengan nilai sig sebesar 0,004 maka $\mathrm{H}_{\mathrm{o}}$ ditolak $\mathrm{H}_{\mathrm{a}}$ diterima yang menunjukkan bahwa variabel risiko bisnis berpengaruh signifikan terhadap return saham. Variabel risiko finansial (X5) mempunyai t hitung $-0,235<\mathrm{t}$ tabel 2,0686 dengan nilai sig sebesar 0,816 maka $\mathrm{H}_{\mathrm{a}}$ ditolak $\mathrm{H}_{\mathrm{o}}$ diterima yang menunjukkan bahwa variabel risiko finansial tidak berpengaruh signifikan terhadap return saham. Variabel risiko likuiditas (X6) mempunyai t hitung 0,239<t tabel 2,0686 dengan nilai sig sebesar 0,813 maka ditolak $\mathrm{H}_{\mathrm{o}}$ diterima yang menunjukkan bahwa variabel risiko likuiditas tidak berpengaruh signifikan terhadap return saham.

Berdasarkan hasil output SPSS besarnya nilai adjusted $R^{2}$ dapat dilihat pada tabel 5 berikut.

Tabel 5

Hasil Koefiisien Determinasi $\left(\mathbf{R}^{2}\right)$

\begin{tabular}{|l|r|r|r|r|r|}
\hline Model & R & R Square & Adjusted R Square & Std. Error of the Estimate & DW \\
\hline 1 &, $884^{\mathrm{a}}$ &, 782 &, 725 & .52473327215 & 1,330 \\
\hline
\end{tabular}

Sumber : Data diolah SPSS 22 output 2015

Nilai Adjusted $R$ Square $\left(\mathrm{R}^{2}\right)$ adalah sebesar 0,725 atau $72,50 \%$. Nilai ini menunjukkan bahwa variabel risiko suku bunga, risiko pasar, risiko inflasi, risiko bisnis, risiko finansial dan risiko likuiditas hanya mampu menjelaskan $72,50 \%$ terhadap variabel return saham sedangkan sisanya $27,5 \%$ dipengaruhi oleh faktor lain yang tidak diteliti. Dengan demikian secara umum model yang digunakan (risiko suku bunga, risiko pasar, risiko inflasi, risiko bisnis, risiko financial dan risiko likuiditas) tidak memiliki cukup pengaruh terhadap variabel dependennya return saham.

\section{SIMPULAN}

Berdasarkan hasil penelitian maka dapat diambil kesimpulan sebagai berikut :

1. Berdasarkan hasil uji secara simultan (Uji-F), dapat diketahui bahwa dari variabel risiko suku bunga, risiko pasar, risiko inflasi, risiko bisnis, risiko finansial dan risiko likuiditas terhadap return saham ada pengaruh signifikan risiko suku bunga, risiko pasar, risiko inflasi, risiko bisnis, risiko finansial dan 


\section{Arna Suryani}

risiko likuiditas secara simultan terhadap return saham pada Industri telekomunikasi di Bursa Efek Indonesia periode 2013-2017.

2. Pengaruh Risiko suku Bunga, Risiko Pasar, Risiko inflasi, Risiko Bisnis, risiko Finansial, dan Risiko Likuiditas secara parsial terhadap retrun saham pada Industri Telekomunikasi yang terdaftar di Bursa Efek Indonesia Periode 2013-2017 : Dari hasil perolehan diketahui bahwa variabel yang berpengaruh secara parsial terhadap return saham yaitu risiko pasar dan risiko bisnis pada Industri Telekomunikasi di Bursa Efek Indonesia periode 2013-2017

3. Dari hasil uji Koefisien Determinasi $\left(\mathrm{R}^{2}\right)$ adjusted $R$ Square $\left(\mathrm{R}^{2}\right)$ diketahui bahwa variabel Risiko Suku bunga, risiko pasar, risiko inflasi, risiko bisnis, risiko finansial dan risiko likuiditas memberikan pengaruh sebesar $72,50 \%$ terhadap variabel return saham sedangkan sisanya 27,5\% dipengaruhi oleh faktor lain yang tidak diteliti pada Industri Telekomunikasi di Bursa Efek Indonesia periode 2013-2017.

4. Dari hasil analisis regresi linear berganda diketahui bahwa variabel yang paling dominan berpengaruh terhadap return saham pada Industri Telekomunikasi di Bursa Efek Indonesia periode 2013-2017 adalah risiko pasar yaitu sebesar 0,604. Risiko pasar merupakan risiko yang tidak dapat dihilangkan melalui diversifikasi. Dengan diversifikasi yang berlebihan maka akan memilki dampak yang negatif yaitu kesulitan untuk mengontrol.

\section{DAFTAR PUSTAKA}

Adisetiawan, R., 2018, Does Stock Split Influence to Liquidity and Stock Return? (Empirical Evidence in the Indonesian Capital), Asian Economic and Financial Review, 8(5), 682-690

Adisetiawan, R., and Yunan Surono, 2016, Indonesia Capital Market Efficiency, British Journal of Economics, Finance and Management Sciences, 11(1), 108-121

Adisetiawan, R., 2017, Does Stock Option Force Bid-Ask Spread and Abnormal Return?, International Research Journal of Finance and Economics, (161), 96-104

Brigham, Eugene F and Joel F. Houston, 2006. Dasar-Dasar Manajemen Keuangan, alih bahasa Ali Akbar Yulianto, Buku satu,Edisi sepuluh, PT. Salemba Empat, Jakarta.

Fahmi, Irham. 2012. Manajemen Risiko: Teori, Kasus, dan Solusi. Bandung: Penerbit Alfabeta Bandung.

Gitman, Lawrence J. 2008. Fundamental of Investing International. $10^{\text {th }}$ ed., International Editions Financial Series. Boston: Addison-Wesley.

Halim, Abdul. 2005. Analisis Investasi. Jakarta: Penerbit Salemba Empat.

Husnan, Suad. 2005. Dasar-dasar Teori Portofolio dan Analisis Sekuritas. Yogyakarta: UPP STIM YKPN.

Sunyoto, Danang. 2013. Metodologi Penelitian Akuntansi. Bandung : Refika Aditama Bandung

Tandelilin, Eduardus., 2007. Analisis Investasi dan Manajemen. Portofolio (Edisi Pertama, Cetakan Kedua). Yogyakarta: BPFE 